\title{
Den analytiske etikk og taylorismens ånd? HR-analyse som ledelseskonsept
}

\author{
Av Hans Olav Stensli *)
}

\begin{abstract}
Sammendrag
Denne artikkelen diskuterer hovedelementer i ledelseskonseptet HR-analyse (HR-A). Vi undersøker hvordan HR-A kan forstås som en faglig diskurs, og hvordan denne er relatert til allerede etablerte diskurser i HRM-feltet. Tilfører HR-analyse nye element til diskurser om ledelse, eller er den først og fremst innleiret i allerede etablerte faglige synsmåter og posisjoner? Ledelseskonsepter kan ha store praktiske konsekvenser i arbeidslivet (Madsen, 2017, s. 181). Vi vil gjennom en innholdsanalyse vise, at HR-analyse som ledelseskonsept kan innebære utfordringer for virksomheter som ønsker å implementere det.
\end{abstract}

\section{Emneord}

Ledelseskonsept, HR-analyse

*) Hans Olav Stensil er dr. polit og førsteamanuensis ved Universitetet i Sørøst-Norge (www.usn.no) 


\section{A. Innledning}

\section{Problemstilling}

Problemstillingen vi søker å besvare er «hvilke hovedelement diskursen om ledelseskonseptet HRA inneholder». Med ledelseskonsept mener vi her et sett av mer eller mindre koherente ideer, verdier og oppskrifter eller resepter for ledelsespraksis (Benders \& Verlaar, 2003, s. 758). Når vi analyserer HR-analyse som et ledelseskonsept, innebærer det at vi tar fenomenet på alvor. Vi bestreber oss på å finne dets forslag til framgangsmåte og rasjonale («oppskrift») for ledelse, og vi gjør dette med en grunnholdning om at et nytt konsept kan vise seg å være en faglig innovasjon. Det siste innebærer også at vi forsøker å sette fenomenet inn i en større faglig sammenheng. I denne artikkelen betyr dette at vi velger å plassere HR-analyse inn i fagfeltet HRM (Human Resource management, eller i norsk språkdrakt «ledelse av menneskelige ressurser»). En slik framgangsmåte kan kritiseres. Det er for eksempel blitt hevdet at fagfeltet HRM er mangelfullt forankret i organisasjonsteori (Bondarouk, Parry \& Furtmueller, 2017; Watson, 2007, s. 101). Vi mener likevel at HRM er et tilstrekkelig rikt felt til å tjene som faglig kontekst. Et interessant trekk ved HRM er nettopp at dette fag- og praksisfeltet er blitt preget av to gjenkjennelige diskurser gjennom de siste tiårene. Den første av disse er diskursen om strategisk HRM (Sparrow, 2015). Den andre er diskursen om evidensbasert ledelse (Pfeffer \& Sutton, 2006). Inngår HR-analyse i disse diskursene, slik at ledelseskonseptet kun er en fortsettelse av disse synsmåtene? Alternativt: utgjør HR-analyse en ny diskurs, eller bidrar den med nytt innhold til etablerte diskurser?

\section{Hva er HR-analyse, egentlig?}

HR-analyse er et ledelseskonsept, som vies stadig større oppmerksomhet (Madsen \& Slåtten, 2018, s. 42). Til tross for dets popularitet som «buzzword» (Angrave, Charlwood, Kirkpatrick, Lawrence \& Stuart, 2016), er bredden av vitenskapelige analyser av konseptet ikke stort (Huselid, 2018; Marler \& Boudreau, 2017). Samtidig er begrepsbruken og definisjonene av fenomenet langt fra enhetlig. En helt generell definisjon er at «HR-analyse handler om å samle inn og analysere HR-data for å kunne fatte bedre beslutninger» (Madsen \& Slåtten, 2018, s. 42). Samtidig kan HR-A ses som del av en pågående diskurs, hvor ulike aktører forsøker å gi meningsinnhold til konseptet. Fremveksten og utbredelsen av HR-A som ledelsesmote er analysert i dette tidsskriftet tidligere (Madsen \& Slåtten, 2018). Den første evidensbaserte review over feltet ble presentert i 2017 (Marler \& Boudreau, 2017, s. 8). Siden den gang er det først og fremst en spesialutgave av tidsskriftet Human Resource Management, som har bidratt med fagfellevurderte artikler om feltet (Huselid, 2018). I tillegg har tidsskriftet Human Resource Management Journal invitert forfattere til å sende inn artikler for en spesialutgave av tidsskriftet med forventet publisering i 2021 (Edwards, Charlwood, Guenole \& Marler, 2018). Et sentralt poeng, som sterkt berører forsøk på å danne oversikt over feltet, er imidlertid at HR-Analyse er et begrep med heterogent og dels uklart innhold (Bassi, 2011; Madsen \& Slåtten, 2018; Shah, Irani \& Sharif, 2017). Skillet mellom publikasjoner som handler om HR-A og 
beslektede tema er derfor plastisk (Edwards et al., 2018). Dette kan bidra til å øke utbredelsen av HR-A, siden konseptet dermed ses som anvendelig på tvers av ulike kontekster (Lawler, Levenson \& Boudreau, 2004). Med unntak av noen få og korte kommentarer (Huselid, 2018, s. 681) er det i publiserte artikler derimot lite refleksjon om prinsipielle utfordringer knyttet til bruken av HR-A i virksomheter (Hamilton \& Sodeman, 2020). I en undersøkelse fra de nordiske landene utgitt i 2017, svarte $80 \%$ av respondentene, at de så HR-A som viktig, men kun 37\% mente at HR-avdelingene utførte denne aktiviteten på en god måte (HR Norge, 2017, s. 4). I en global undersøkelse publisert i 2019 rapporterte kun 26\% av respondentene, at de brukte teknologi og analyse på en effektiv måte (Deloitte, 2019, s. 93). Til tross for at vi kan være kritiske til disse tallene, underbygger de, at medarbeidere ser på analyse som et forbedringspotensial i egen organisasjon.

Vi diskuterer derfor hvordan HR-analyse kan forstås som ledelseskonsept med bakgrunn i de postulater tekster om HR-analyse hittil har frambrakt. Det er av denne grunn valgt et kritisk perspektiv, i kontrast til flere av de eksisterende tekster om fenomenet, som tidvis kan etterlate et inntrykk av, at man med HR-A har funnet HRMs hellige gral. Det er påtakelig at fenomenet i likhet med tidligere oppskrifter (strategisk HRM gjennom HR-transformasjon, evidensbasert ledelse) gir løfter om økt prestisje for HR som organisatorisk funksjon og fag, i dette tilfellet gjennom mer «vitenskapelig» tilnærming og håndfaste analyser (Lawler et al., 2004; Levenson, 2005; Mondore, Douthitt \& Carson, 2011; Ulrich \& Dulebohn, 2015).

\section{Oversikt over artikkelen}

Vi vil i del B gi en utdyping av aktuelle begreper innen HR-analyse, samt kort diskutere HRM som faglig kontekst for senere diskusjon av HR-analyse. I del C vil vi presentere de mest sentrale påstandene om HR-analyse i de tekster, som vi har valgt å analysere. Del D er en drøfting av de mest sentrale implikasjonene av tekstene. Vi oppsummerer funnene i del E.

\section{B. Sentrale Begreper og kontekst for å vurdere HR-analyse \\ 1. «HR analytics» eller «workforce analytics»?}

Det er særlig stor interesse til resultatet, når et anerkjent tidsskrift som Human Resource Management kommer med en spesialutgave om «workforce analytics» i 2018. Allerede ved redaktør Mark A. Huselids (2018, s 679) introduksjon til utgaven ser vi, at begrepet HR Analytics er byttet ut med workforce analytics. Slik er det også i artikkelen til Levenson (2018) i samme nummer, mens Dana Minbaeva benytter begrepet «human capital analytics (HCA)» (Minbaeva, 2018, s. 701). En kritisk leser kan spørre seg, hva årsaken er til at begrepet HR Analytics ikke benyttes i et HRMtidsskrift, når det later til at innholdet i de ulike begrepene er det samme. I følge Huselid betyr bruken av «workforce analytics» at man i mindre grad vektlegger HR-funksjonen, og i større grad 
ser på hvordan arbeidsstyrken og -kraften som helhet påvirker produktivitet (Huselid, 2018, s. 680). En liknende form for argumentasjon finner vi hos Guenole et al. (2017). Begrepsmessig hevder forfatterne, at «HR analytics» innebærer HR-funksjonens analyser for HR sitt eget bruk (ibid, s. 16). «Workforce analytics» er ifølge forfatterne mer presist, da det er «more descriptive of all workers (not just employees) and includes contract staff, managed services, freelancers, and other people. The term also allows for the future inclusion of machines that will replace current jobs performed by humans" (ibid, s. 17). Det er grunn til å stille kritiske spørsmål til dette. Hvilke utfordringer løses ved en endring av begrepet fra HR-analyse til «workforce analytics»? Når workforce analytics også inkluderer mennesker med atypisk tilknytningsform til virksomheten, er det ønskelig at man er mer spesifikk på, hva man legger i «other people». For oversiktens skyld vil vi i det følgende fortsette å bruke forkortelsen HR-A om både HR Analytics, workforce analytics og human capital analytics. Huselid (2018) hevder det er en stor økning i interessen for HR-A både blant praktikere og forskere. I likhet med Marler og Boudreau (2017) er han optimist på fenomenets vegne (Huselid, 2018, s. 679). Huselid er en av nokså få forfattere, som peker på utfordringer knyttet til HR-A som ledelseskonsept (ibid, s 681). Disse er listet opp som spørsmål, men gis ingen problematisering. Her kommer imidlertid også et moment opp som vi i denne artikkelen anser som en utfordring ved HR-A. Huselid (ibid, s 681) formulerer det slik: «How will the workforce react to significantly enhanced measurement and monitoring?». Arbeidsstyrken i HR-A er et objekt, et objekt for registrering og analyse, og et objekt for «tiltak». Spørsmålet er, hvorledes dette objektet vil reagere på økt bruk av registrering og målinger. Huselid forfølger imidlertid ikke spørsmålet.

\section{Etablerte diskurser i HRM-idealtyper}

Vi hevder at det er særlig to diskurser som har vært fremtredende i HRM-faget de siste tiårene (Boon, Paauwe, Boselie \& Den Hartog, 2009; Rynes, Giluk \& Brown, 2007); den ene er at HRM skal bidra på et makronivå for bedriften gjennom strategi. Den andre handler om at HRM skal være en bidragsyter på mikronivå gjennom praktisering av evidensbasert ledelse (Pfeffer \& Sutton, 2006; Rynes, Colbert \& Brown, 2002). Å gi noen gjennomgang av disse ville føre for langt her. Det finnes en rekke oversikter over temaene (Boxall \& Purcell, 2016; Kaufman, 2015; Kuvaas \& Dysvik, 2016; Mikkelsen, 2014). HRM-feltet har i årtier har vært på jakt etter en «medisin», som kan øke HRMs prestisje i praksisfeltet (Kaufman, 2020, s. 54-55). David Ulrich (2009) sin modell for HR-transformasjon kan i begrenset grad (Boglind, Hällsten \& Thilander, 2014; Guest \& King, 2004) ses på som et vellykket bidrag i så måte. Når det gjelder evidens, er det påpekt et ikke ubetydelig gap mellom HRM-forskning og praksis (Rynes et al., 2002) i den forstand, at praktikerne i HR-feltet i begrenset grad legger forskning til grunn for utøvelse av HRM (Kuvaas \& Dysvik, 2016, s. 238). Det kan se ut til at implementering av mye omtalte ledelseskonsepter er en utfordring. 
Diskurs

\begin{tabular}{|l|l|l|l|}
\cline { 2 - 4 } & & Strategisk HRM- & Evidensbasert \\
Hovedinnhold & $\begin{array}{l}\text { makro } \\
\text { strategi og organisatorisk } \\
\text { ytelse }\end{array}$ & $\begin{array}{l}\text { Intendert strategi, } \\
\text { strategisk endring, } \\
\text { konkurransefortrinn }\end{array}$ & $\begin{array}{l}\text { Fremvoksende strategi, } \\
\text { læring, } \\
\text { avkastning }\end{array}$ \\
\cline { 2 - 4 } & $\begin{array}{l}\text { Primært kompetansebehov } \\
\text { for HR-funksjonen }\end{array}$ & Forretningsforståelse & $\begin{array}{l}\text { Innsikt i psykologiske } \\
\text { emner }\end{array}$
\end{tabular}

Tabell 1: Sentrale diskurser i faget HRM

Tabell 1 gir et reduksjonistisk sammendrag av innholdet i de etablerte diskursene i HRM. Når vi skal se hvilket bidrag HR-A gir til feltet, blir det sentralt å analysere i hvilken grad HR-A kun innebærer en videreføring av de etablerte diskursene, eller om den bidrar med noe kvalitativt nytt.

\section{Hovedelement i HR-analyse i henhold til et udvalg af tekster}

\section{Om utvalg av tekster}

Før vi begynner analysen av HR-As innhold, er det hensiktsmessig å gi noen korte kommentarer om utvalget av tekster, vi skal diskutere. Om vi tar utgangspunkt i hypoteser om ledelsesmoter, kan vi tenke oss et spekter av tekster, som kommer fra tilbudssiden ved moteproduksjonen (Abrahamson, 1996, s. 260). En første gruppe kan være det, vi kan kalle tekster fra praksisfeltet. Den andre er de tekster, som består av fagfellevurderte artikler i vitenskapelige tidsskrift. I en tredje gruppe, en form for mellomposisjon, finner vi de tekstene, som kan ses på som forsøk på å bygge bro mellom vitenskapelige tekster på den ene siden og tekster med praktikere som målgruppe på den andre. Tekster fra praksisfeltet utgjør et mildest talt stort og heterogent felt, og det er derfor ikke praktisk mulig å dekke dette innenfor rammene av denne artikkelen.

Når det gjelder fagfellevurderte artikler, er dette feltet mer oversiktlig. Her vil vi begrense oss til å omtale to sentrale tekster i spesialutgaven av Human Resource Management fra 2018, samt artikkelen av Marler og Boudreau (2017). Det er to grunner til dette utvalget. For det første er artikkelen til Marler og Boudreau, så langt vi kan se, den første evidensbaserte oversikten over HRA. For det andre kan spesialutgaven til det nevnte tidsskriftet ses på som et forsøk på å danne «skole» for studiet av HR-A, ved at eksemplariske arbeider blir trukket fram i et tidsskrift med betydelig anseelse. Dernest vil vi gi en analyse av to populære bøker om HR-A, som faller inn i den tredje gruppen av tekster, som vi nevnte over. Disse utgivelsene er skrevet av forfattere med 
forskerkompetanse, samtidig som de har et avgjort praktisk formål. Vi mener at denne typen utgivelser ikke bør neglisjeres i studier av den faglige diskursen om HR-A. Generelt er det snarere blitt hevdet, at det er et behov for litteratur som nettopp søker å bygge bro mellom praksisfeltet og akademia (Rynes et al., 2007).

I det følgende vil vi, med et heuristisk formål, dele tekstene i tre hovedkategorier. Hver kategori inneholder en «resept» på hva HR-A er som ledelseskonsept. Den første tilsier at HR-A er et konsept som primært hjelper virksomheten på et overordnet nivå, som vi her kaller makro. Den andre peker mot et ledelseskonsept som handler mer om mikro; egenskaper ved medarbeiderne på individnivå. Den tredje kan vi se på som en mellomposisjon: meso betegner en større vektlegging av grupper og kapabiliteter internt i organisasjonen.

\section{Makro: HR-analyse er et ledelseskonsept for å utøve virksomhetsstrategi}

Marler og Boudreaus (2017) artikkel er, så langt vi kan se, den første «evidensbaserte» review av HRA som felt, til tross for at «måling» av forskjellig slag har vært diskutert i HR-litteratur fra slutten av 1970-tallet (Bassi, 2011). Forfatterne bruker systematisk betegnelsen «HR Analytics» for dette formålet. De hevder (Marler \& Boudreau, 2017, s. 14), at HR-A skiller seg fra «HR metrics», men at meningsinnholdet i begrepet fremdeles er uklart. Interessant nok peker de på hvordan flere har fremhevet hvordan HR-A skal demonstrere, hvordan «mennesker» eller «menneskelige ressurser» kan ha «direkte innvirkning» på sentrale forretningsmål (ibid, s 14-15). Med andre ord synes HR-A her å være innleiret i den større diskursen vi kan kalle strategisk HR (SHRM) (Døving \& Nordhaug, 2010; Guest \& King, 2004; Kaufman, 2015; Laudal \& Mikkelsen, 2014; Nordhaug, 1987; Torrington \& Hall, 1996). Forfatterne er eksplisitte på, at de selv vurderer dette som en mulig vei for å heve HRMs status (Marler \& Boudreau, 2017, s. 15); «HR Analytics appears to offer more than HR Metrics through its potential to connect HR processes and decisions with organizational performance, which is an avenue to elevating HRM to having a more strategic role and joining other business functions at the strategy table». Samtidig vedgår forfatterne, at det er et åpent spørsmål, om HR-A faktisk vil bli institusjonalisert som en HR-praksis. Det siste spørsmålet er også diskutert av andre forskere (T. Rasmussen \& Ulrich, 2015). HR-funksjonene kan mangle både analytiske ferdigheter, strategisk innsikt, innflytelse i toppledelsen og HR informasjonsteknologi for å lykkes (Marler \& Boudreau, 2017, s. 18). Et hovedfunn i Marler og Boudreaus analyse er, at det etter deres skjønn er to paradokser ved HR-A. For det første en mangel på vitenskapelig evidens, og for det andre, at konseptet er tatt i bruk i mindre grad i virksomheter enn dets popularitet som et mye omtalt konsept skulle tilsi. 
Alec Levensons (2018) artikkel «Using workforce analytics to improve strategy execution» problematiserer analysenivået i HR-A. Om vi oppsummerer hans synsmåter, kan vi si, at han ser på feltet som for dominert av metodologisk individualisme. Levenson legger til grunn, at utfordringene knyttet til HR-A dreier seg mer om, hva man eksplisitt ser som hovedmålet med HR-A, og hva implikasjonene for gjennomføring av HR-A dermed blir. Han argumenterer her sterkt, for at analysen må ta utgangspunkt i spørsmål om virksomhetens konkurransefortrinn og spørsmål knyttet til langsiktig organisatorisk ytelse, på bekostning av analyse på individ- og rollenivå (Levenson, 2018, s. 685). Med andre ord kreves det etter Levensons oppfatning en vektlegging av et systemperspektiv. Levenson vektlegger makro foran mikro. Det er dekkende å si at Levenson setter opp et programmatisk skjema for hvordan HR-A bør gjennomføres: først skal man analysere konkurransefortrinn og -ulemper. Dette vil gi analytikerne evne til å prioritere mellom tema og tiltak. Dernest kommer det Levenson kaller «Enterprise analytics» (ibid, s. 687), og som han sammenfatter som aggregerte nivå over individnivå (grupper, seksjoner, avdelinger osv i organisasjonen). Og så; «the third step is to apply, if needed, human capital analytics, which I use to refer to traditional workforce analytics that focus exclusively at the individual level» (ibid, s. 687). Analyser på rolle-/individnivå er altså mer unntaksvis nødvendig i HR-A. Han argumenterer med, at en for sterk vektlegging av mikro har minst to ulemper for praktikere. For det første kommer organisatorisk ytelse i bakgrunnen. For det andre er forskningen om individuell atferd svært omfattende å sette seg inn i, og favoriserer multivariat statistisk analyse, som han mener forsterker ekskluderingen av systemnivået (ibid, s. 696). Om HR-A skal være et middel for å bedre utøvelsen av strategi, må HR-A snarere vise de behov for endringer, som må til for bedre ytelse for virksomheten.

\section{Mikro: HR-analyse er et ledelseskonsept for evidensbasert ledelse}

Thomas Hedegaard Rasmussens «Målbar HR - En praktisk guide til datadrevet HR-ledelse», er en relevant utgivelse å ta med her (T. H. Rasmussen, 2014). Boken retter seg mot den praktiske utøvelse av HR-A. Den interesserte praktiker vil trolig også finne mange nyttige tips, forklaringer og framgangsmåter i denne boken. Vi skal se nærmere på noen sentrale forutsetninger forfatteren gjør. Rasmussen deler Minbaevas og Levensons vektlegging, av at HR-A må ta utgangspunkt i «forretningens behov» (ibid, s. 29). På skalaen mellom mikro og makro ligger utgivelsen imidlertid, etter vårt skjønn, mest på mikrosiden. Det er et markant skille mellom Levensons og Rasmussens tilnærming til HR-A på dette punktet. Og her hevder boken, at det finnes en rik forskningslitteratur, som praktikere kan lære av. Rasmussen legger betydelig vekt på, at praktikerne må anvende publisert forskning om effekter av HR-tiltak (ibid, s. 54-55). Således føyer boken seg inn i rekken av HR-faglige utgivelser, som legger stor vekt på evidens. Han anbefaler analytikerne kun å fokusere «på de absolut bedste tidsskrifter» (ibid, s. 55). Som en avslutning av boken lister Rasmussen opp 10 utvalgte artikler, som er «anbefalet læsning» (ibid, s. 167-168). 8 av de 10 artiklene, han anbefaler, er hentet fra tidsskrift, som vi kan rubrisere under psykologifaget. Det må være legitimt å påpeke, 
at dette gir emnet et fokus, som i stor grad retter seg mot betydningen av mikro-nivået i HRM. Det er også grunn til å peke på, at Rasmussen legger til grunn en nokså «streng» bedømming av, hvilke tidsskrift som er av god kvalitet (ibid, s. 55). I tillegg til vektleggingen av forskning innen psykologi og understrekingen av, at praktikere må legge evidens til grunn, målbærer Rasmussen også, at kvantitativ metode har den mest sentrale plassen i HR-A. Igjen står dette i kontrast til synsmåter hos Levenson (2018). Riktignok åpner Rasmussen for, at kvalitativ metode også kan ha sin plass i HR-A, men leseren forstår tidlig, at det er «harde» data som teller. Det er et åpent spørsmål, om ikke dette snevrer inn feltet, jf diskusjonen hos Levenson (2018).

\section{Et mesonivå}

I tillegg til dimensjonene over, finner vi en form for mellomposisjon på meso-nivå i litteraturen om HR-A. Her kan det være mulig å snakke om et bidrag, som ikke passer beleilig inn i mikro eller makro i sine rendyrkede former. To tekster viser dette.

Minbaeva (Minbaeva, 2018) forsøker med sin artikkel både å sette opp sentrale prinsipper for HR-A forstått som "human capital analytics" (HCA) og samtidig å gi eksempler på, hvordan HR-A kan utvikles og utføres. Hensikten med det, forfatteren selv kaller anekdotiske observasjoner, er å illustrere de utfordringer, virksomheter kan møte i sine forsøk på å bygge HCA. Artikkelen bygger eksplisitt på det ressursbaserte perspektivet på å skape konkurransefortrinn (ibid, side 701). Minbaeva ser HCA som en organisatorisk kapabilitet grunnfestet i tre «mikrokategorier» (individ, prosesser og struktur), og at den utgjøres av tre dimensjoner (datakvalitet, analytisk kompetanse og evne til strategisk handling). En overordnet konklusjon er at det kreves mye for å skape HCA. Således må analyseteamet ha evnen til å «measure variables, build causal models...test them in the correct way, and tell a compelling story» (Minbaeva, 2018, s. 703). Dette kommer i tillegg til at organisasjonen selvsagt må sikre tilfredsstillende kvalitet på sine data. Dernest kommer den iboende utfordringen med å overbevise toppledelsen i virksomheten om at ressurser brukt på HCA er vel anvendte. Hun mener, at svaret på dette er å la evidensbasert analyse munne ut i konkrete anbefalinger til oppfølging: «the results must be actionable, such that they can be easily transferred into strategic actions and, thereby, have a measurable impact» (Minbaeva, 2018, s. 704). Vi kan merke oss, at antakelsen rommer to forutsetninger for at HR-A skal lykkes; (i) analysene må gi resultater av en slik art at det er «enkelt» å anvende den i strategiske handlinger, og (ii) organisasjonen må ha både evne og vilje til å gjennomføre disse. Så langt skal vi nøye oss med å spørre om mangel på (i) og/eller (ii) nødvendigvis kan forklares av analytikernes dyktighet.

Nigel Guenole, Jonathan Ferrar og Sheri Feinzigs «The Power of People - learn how successful organizations use workforce analytics to improve business performance" (2017) er rettet mot praktikere. I likhet med Rasmussen har vi her å gjøre med forfattere, som både har forskerkompetanse, og som har betydelig erfaring fra praksisfeltet. Som hos Rasmussen (2014) 
beskrives et antall trinn i et analyseprosjekt. Selve oppskriften, som boken leverer, tar utgangspunkt i det å formulere forretningsmessig viktige spørsmål. De siterer Alec Levenson i betydelig grad på dette punktet (Guenole, Ferrar \& Feinzig, 2017, s. 28-29). Det er et tydelig preg ved oppskriften, at analyse skal gjennomføres som noe som minner om en forskningsprosess. Dette medfører også, at virksomhetens analytikere må ha, eller skaffe seg, forskningskompetanse. Boken bruker derfor noe plass på å gi en framstilling av forskningsdesign. Målet må være å gi kausalforklaringer (ibid, s. 45) på sosiale fenomen, som har betydning for organisatorisk ytelse. Ifølge forfatterne er det et stort potensial for analytikerne å hente i kvantitative analyser, ikke minst fordi disse kan benyttes til å predikere atferd; «Given what we currently know about employees, the general pattern in predictive analysis is to estimate their future behavior at work» (ibid, s. 49). Forfatterne gir her en løfterik framstilling av, hva HR-A kan utrette-om man ser det i et styringsperspektiv. Når det gjelder det siste, anvender forfatterne et eget kapittel (ibid, kap. 8) på interessenter (stakeholders), hvor de også inkluderer fagforeninger og «arbeidsstyrken»(«the workforce»). Samtidig er kapittel 16 titulert «Overcome Resistance». Hvem er det så, som skal beseire motstand, og hvem er det som yter motstand mot HR-A, og som derfor må «beseires»? Det synes klart, at forfatterne mener det er selve utøverne av analyse som møter motstanden (ibid, s. 239-240). De presenterer en egen tabell over årsaker til motstand, og det de mener er passende tips for å møte den samme motstanden (ibid, s. 250-251). Det hele er nærmest en liten katalog med utfordringer og ditto løsninger. Bidraget til Guenole et al (2017) faller inn i kategorien diskurs på mesonivå, særlig pga. dets vektlegging av ulike interessentgrupper.

\section{Diskusjon}

\section{HR-analyse som diskurs}

De tekstene vi har gjennomgått foran, lar seg ikke enkelt plassere i renskårne kategorier. Imidlertid vil vi hevde, at de innehar noen sentrale dimensjoner, som utgjør relativt klare forslag til innhold i HR-A. For å søke å klargjøre disse, drister vi oss til å framstille disse tabellarisk. Vi må understreke, at dette er en typologi av idealtyper i weberiansk forstand (Weber, 2019, s. 85).

En slik oppstilling må for det første svare på, hva som er de dominerende dimensjonene, i hvordan HR-A skal forstås. Vi mener her, at de fem tekstene, vi har valgt ut, peker mot tre slike diskurser. Den første er, at HR-A kan forstås som et hjelpemiddel og metode for å fremme virksomhetsstrategi på makronivå. Alle tekstene nevner dette i form av «forretningsorientering» og beslektede begreper. Imidlertid er det et skille mellom tekstene, i hvilken grad de legger mest vekt på mikro, meso eller makro. Vi mener tekstene til Levenson (2018) og Marler og Boudreau (2017) framhever strategi på makroplanet som det avgjørende bidraget, som vil gi HRM en plass ved bordet, hvor strategi utformes. Rasmussen (2014) behandler HR-A i større grad som et bidrag på mikronivå. Her er det 
en dreining mot, at HR-A skal hjelpe organisasjoner til å søke og utnytte evidens om HR i sine beslutningsprosesser. Med andre ord mener vi, at disse tekstene i ulik grad vektlegger henholdsvis strategi på makronivå, og evidens på et mikro-nivå. I dette perspektiver gir tekstene en framstilling av HR-A som et ledelseskonsept som er et supplement til etablerte faglige posisjoner. Samtidig har vi i tekstanalysen også funnet en dimensjon som ikke lett lar seg plassere i de etablerte diskursene; nemlig de tekstene som presenterer HR-A som et ledelseskonsept på meso-nivå. Disse bidrar til det som kan bli en diskurs med nytt innhold. Her blir HR-A framstilt som et ledelseskonsept som kan knytte makro og mikro bedre sammen i HRM-feltet.

For det andre kan en slik typologi av idealtyper hjelpe oss til å konseptualisere noen avgjørende implikasjoner, som diskursene gir. Disse implikasjonene går utover det prinsipielle, og langt inn i, hvordan HR-A praktisk skal utføres som en organisatorisk prosess. Siden vi nå befinner oss på et konseptuelt nivå, kan vi sette opp diskursene med noen tilhørende implikasjoner, som vi har gjort i tabell 2 under.

Diskurs

\begin{tabular}{|c|c|c|c|c|}
\hline & & Strategi-makro & $\begin{array}{l}\text { Kapabilitetsbygging- } \\
\text { meso }\end{array}$ & Evidens-mikro \\
\hline \multirow[t]{3}{*}{ Implikasjon } & $\begin{array}{l}\text { HR-As bidrag til } \\
\text { strategi og } \\
\text { organisatorisk } \\
\text { ytelse }\end{array}$ & $\begin{array}{l}\text { Intendert strategi, } \\
\text { strategisk endring, } \\
\text { konkurransefortrinn }\end{array}$ & $\begin{array}{l}\text { Bygge organisatoriske } \\
\text { kapabiliteter }\end{array}$ & $\begin{array}{l}\text { Fremvoksende } \\
\text { strategi, læring, } \\
\text { avkastning }\end{array}$ \\
\hline & $\begin{array}{l}\text { Primært } \\
\text { kompetansebehov }\end{array}$ & Forretningsforståelse & $\begin{array}{l}\text { Evnen til å knytte } \\
\text { sammen kunnskap om } \\
\text { forretningen og de } \\
\text { menneskelige ressursene }\end{array}$ & $\begin{array}{l}\text { Innsikt i psykologiske } \\
\text { emner }\end{array}$ \\
\hline & $\begin{array}{l}\text { Mest sentrale type } \\
\text { analyse }\end{array}$ & Systemanalyser & Analyse av kapabiliteter & $\begin{array}{l}\text { Kvantitative } \\
\text { multivariate analyser }\end{array}$ \\
\hline
\end{tabular}

Tabell 2: idealtypiske trekk ved tre diskurser om HR-analyse

Tabell 2 er et forsøk på å framstille noen særegne trekk ved de tre diskursene. Disse kan vi se på som grunnleggende antakelser om HR-A.

\section{Antakelser om HR-As bidrag til faglige diskurser om ledelse}

Vi kan se, at disse tre diskursene gir forskjellige inntak til, hvordan HR-A yter bidrag til organisatorisk ytelse og strategi. For om den ene retningen er mer rettet mot evidens på mikroplanet, 
er det like fullt mulig å se dette som (et indirekte) bidrag til virksomhetens strategi. Mikrodimensjonen kan legge vekt på organisatorisk læring og dermed fremvoksende strategi ved å peke på, hvilke typer HRM som gir avkastning. Makro-antakelsen vil på sin side kunne legge vekt på, at HR-A gir direkte bidrag til intendert strategi. Med andre ord kan analysene anvendes i planlagt, rasjonell endring (Mintzberg, Ahlstrand \& Lampel, 2009). Meso-nivået har potensiale til å bidra med en ny diskurs, gjennom et ledelseskonsept som skal binde sammen mikro og makro i HRM.

Når det gjelder behovet for kompetanse hos analytikerne, vil makrodimensjonen strategi peke mot behovet for god forretningsforståelse. Skal HR-A anvendes for å hjelpe til med god strategiimplementering (Levenson, 2018), er dette en helt nødvendig kompetanse i analyse-teamet. Mikrodimensjonen evidens vil snarere peke på behovet for å kunne forstå, tolke og presentere forskning på individnivå (eksempelvis medarbeideres motivasjon). I en diskurs om HR-A på mesonivå er imidlertid evnen til å knytte sammen kunnskaper om forretningen og de menneskelige ressursene det sentrale.

Så er det endelig slik, at vi på bakgrunn av det over kan se for oss, at de tre diskursene kan ende opp med tre forskjellige idealtyper for, hva som er den mest sentrale typen av analyser. Ut fra en antakelse om, at HR-A skal benyttes i implementering av intendert strategi, vil denne idealtypen helle mot systemanalyser. Her må analysen gjelde HR-spørsmål, som angår hele virksomhetens ytelse og konkurransefortrinn, formodentlig sett opp mot virksomhetens omgivelser. Derimot vil en forutsetning om analyse bygget på mikronivået mer typisk bestå av kvantitative analyser som tar utgangspunkt i individnivå. Her er det variable på medarbeidernivå og sammenhengen mellom disse og organisasjonsatferd, som er et sentralt inntak til kunnskap som bidrar mest til organisasjonen. Humankapitalen er en type ressurs, som kan kvantifiseres og dermed analyseres som andre «harde» data. Igjen blir meso-varianten av HR-A en slags mellomposisjon, da man her kan argumentere for at ledelseskonseptet skal hjelpe virksomheten til å bygge relevante organisatoriske kapabiliteter.

En slik typologi kan ses som hypotese-genererende, og som et forsøk på å skape forklaringer (Stinchcombe \& Merton, 1968) på hva HR-A kan bidra til som ledelseskonsept. Om vi ser på HR-A som en diskurs, er det nærliggende å hevde, at de ovennevnte tekstene i stor grad viser, at HR-A er innleiret i to eldre diskurser. Disse kan vi kalle strategisk HRM (SHRM) (Boxall \& Purcell, 2016) og evidensbasert ledelse (Pfeffer \& Sutton, 2006) - begge kan ses som diskurser om ledelse. Det gjenstår å se om den tredje underdiskursen, på meso-nivå, vil innebære en innovasjon. I sum betyr dette, at HR-A har et potensiale for å bli «solgt inn» som et ledelseskonsept i HRM-feltet på forskjellige måter (Lawler et al., 2004). Alle idealtypene skissert over har ventelig et publikum i så måte. Hvor vidt makro, meso eller mikro (i vår sjargong) vil bli mest dominerende, eller om disse perspektivene vil leve side om side, er det i skrivende stund umulig å si. Det er også interessant å se, om debatten på området vil få likhetstrekk med diskusjonen om «psykologiseringen» av HRM som akademisk fagfelt 
(Budd, 2020; Godard, 2020; Harley, 2015; Troth \& Guest, 2019). Et annet spørsmål er, om andre funksjoner enn HR i virksomhetene (T. Rasmussen \& Ulrich, 2015) vil kolonisere HR-A.

Eksempelvis kan en tenke seg, at det i større virksomheter kan være markedsføringsavdelinger, økonomifunksjoner eller andre stabsledd, som har den metodiske kompetansen til å gjennomføre HR-A. Den prinsipielle motforestillingen mot dette er, at disse funksjonene presumptivt ikke har samme fagkompetanse på HRM som HR-funksjoner har. Dette gjør, at enkelte forskere advarer mot en utvikling, der HR-A blir enda mer preget av et styringsperspektiv enn av lederskap med mennesker i sentrum (Angrave et al., 2016). Basert på de tekstene vi har behandlet over, og vår oppsummering av dimensjoner i tabell 2, kan en tenke seg flere områder av HR-A, som bør problematiseres. I det følgende vil vi begrense oss til å se nærmere på to faktorer, som vi mener er spesielt viktige. Vår antakelse er, at en klargjøring av disse vil bidra til en realistisk vurdering av ledelseskonseptet.

\section{Et spørsmål om kompetanse?}

Et første spørsmål er, hvordan kompetanse påvirker evnen til å utføre analyse på en måte, som bidrar til bedre implementering av virksomhetens strategi, bedre organisatorisk ytelse eller hvilke andre mål, vi ønsker å formulere. Det er en tendens i litteraturen til å stille nettopp dette spørsmålet, og gjerne da med et noe pessimistisk svar om, at HR-funksjonen i for stor grad mangler «den rette» kompetansen og ferdighetene som skal til for å få HR-A til å fungere etter intensjonen (Angrave et al., 2016; T. Rasmussen \& Ulrich, 2015). Videre har det i rapporter og den empiriske forskningen, som er gjort på området (Deloitte, 2019), også blitt pekt på at manglende kompetanse hos de, som skal utføre analysene, er en årsak til mangelfull implementering av HR-A. Dette skal vi selvsagt ikke avvise.

Samtidig er det nærliggende å spørre, om ikke kompetanseaspektet bør presiseres og undersøkes langt mer detaljert. Er HR-funksjonens noe forsiktige tilnærming til kvantitativ og strategisk analyse (Angrave et al., 2016; Guest \& King, 2004) et resultat av mer enn «manglende kompetanse»? I en nylig publisert artikkel peker Greasley og Thomas (2020) på, at skepsisen kan ha mye å gjøre med rolle og syn på HRMs egenart hos praktikerne. For de med en rolle tett på medarbeiderne i organisasjonen er det sannsynlig, at kvantitativ analyse ikke alltid blir oppfattet å fange opp kompleksiteten og tolkningsmangfoldet i det sosiale systemet en organisasjon er (Morrell \& Learmonth, 2015; Purcell, 2014). Greasley og Thomas (Greasley \& Thomas, 2020) finner videre, at toppledere var mer positive til kvantitative funn enn det HR-ledere var. Det er ikke usannsynlig, at det å være både faglig og operativt nærmere problemstillingene, som HR-ledere presumptivt er i HRfaglige spørsmål, gjør en mer skeptisk til sterk vektlegging av virksomhetsstrategi, og tallene, som måtte komme ut av de statistiske analysene. Med andre ord er det grunn til å undersøke følgende rudimentære hypotese: Er litteraturen om HR-A for ensidig opptatt av ambisiøse tanker om strategiske bidrag, kvantitativ analyse og evidens til, at praktikere finner konseptet verdt den 
nødvendige investeringen i tid og teknologi (Angrave et al., 2016, s. 9)? Videre kan en spørre, om ikke hele den fysiske situeringen av analytikerne og HR-lederne i organisasjonen i seg selv har konsekvenser for tenkningen om og praktiseringen av HR-A. HR-funksjonens analytikere er både deltakere og tilskuere (Skjervheim, 1996) i virksomhetens HRM, herunder analysearbeid, som gjelder HR-spørsmål. I større grad enn eksterne akademikere er de innvevet (Geertz \& Darnton, 2017) i de strukturene, de selv skal analysere. Ledelse handler om makt (Einarsen \& Skogstad, 2015). Og ett aspekt av sosial makt er sosial avstand. Dette er en hypotese på, hvorfor praksisfeltet kan ha temmelig heterogene reaksjoner til HR-A i dagens utgaver. Med andre ord bør vi ikke utelukke at økt sosial avstand kan gi et mer instrumentelt forhold til analyse; jo lengre unna man er analyseobjektet, jo mindre er man emosjonelt knyttet til det. Vi kan også føre det lengre enn som så, og si, at HR-A kan brukes instrumentelt for å legitimere ledelsespraksiser som kan være kontroversielle hos noen interessenter i virksomheten (Angrave et al., 2016, s. 1).

\section{Et Tayloristisk ledelseskonsept?}

Dette fører oss til det andre hovedpunktet, som ventelig er mer kontroversielt, enn spørsmålet om kompetanse. Det gjelder, hvilken legitimitet HR-A vil ha, også i den dobbeltheten som konseptet bærer på, hvor den både kan framstå som verdinøytral («vitenskapelig») analyse og på den annen side tjene som legitimering av ledelse og policy i virksomheter. Den andre rudimentære hypotesen, om hva forskningen i framtiden bør søke å gi svar på, er, om HR-A kan påvirke organisatorisk tillit og -klima (Julsrud, 2018) på slike måter, at den påvirker atferd i organisasjonen. Teoretisk kan en tenke seg, at HR-A kan ha målbare effekter på implementering av strategi (Levenson, 2018) og bygging av organisatoriske kapabiliteter (Minbaeva, 2018). Samtidig kan det være grunn til å peke på, at nettopp nærheten mellom analytikere og de analyserte innenfor en og samme virksomhet kan medføre en form for interferens i analysene. Det er ikke utenkelig, at både selvoppfyllende og selvødeleggende profetier (Gilje \& Grimen, 1995) kan finne sted i HR-A. Dette er potensielt en betydelig problemstilling, som praktikere bør være bevisst på. Det er påfallende, at problemstillingen ikke blir reist i noen av de tekstene, som vi har lagt til grunn i denne analysen. Det sentrale spørsmålet er, om eksplisitt bruk av HR-A over tid vil gi organisasjoner konkurransefortrinn eller -ulempe (Angrave et al., 2016). Vi ser ikke noen grunn til, at man i slike vurderinger skal ekskludere indirekte effekter av, at arbeidsstyrken gjøres til et analyseobjekt av den samme virksomheten, som medarbeiderne er ansatte i. HR-A krever data, og det betyr at man må registrere målbare data i virksomheten. Hvordan skal man så unngå at de ansatte opplever HRA som digital taylorisme? Videre er det problematisk å anse forskere som helt verdinøytrale. Etter vårt skjønn er det enda mer problematisk å forutsette, at analytikere eller bestillere av analyser internt i en virksomhet på noen måte er nøytrale observatører i de spørsmål, som skal undersøkes. Dette kan dreie seg om bevisste og ubevisste kilder til bias. Framfor alt vil det være slik, at analyser og utfallet av disse vil ha politiske dimensjoner i en virksomhet av noe størrelse og kompleksitet. 
Maktforhold i virksomheten kan påvirke et analysearbeid i alle dets ulike faser. Dette er ikke reflektert i de tekstene vi har analysert her.

Videre kan en se for seg, at de tre diskursene i HR-A vil medføre ytterligere utfordringer, også utover etiske problemstillinger. I makro-dimensjonen som primært handler om å fremme implementering av strategi, blir spørsmålet om, hvor bredt de ulike interessentene er representert i arbeidet aktualisert. Her kan en tenke seg, at HR-A først og fremst blir et redskap for toppledelsen (Caldwell, Truong, Linh \& Tuan, 2011). I mikro-dimensjonen kan det være grunn til å advare mot en for sterk grad av kortsiktig reduksjonisme, hvor spørsmålet «lønner dette seg?» blir enerådende. Om økonomisk avkastning er målet, blir det også helt fundamentalt å kunne påvise, det vil si måle, en slik avkastning. Dette fører i alle fall to ting med seg. For det første er det kun de målbare effektene av virksomhetens praksiser, som det er verdt å undersøke, noe som kan medføre en innsnevring av det analytiske inntaket til ledelse. Dernest blir tidsaspektet svært viktig: om vi ikke kan finne målbare positive effekter av en praksis innen «rimelig» tid, er det vel rasjonelt å forkaste eller endre praksisen? Da blir i alle fall ett av spørsmålene, hva vi skal sammenlikne resultatene med. Her vil enkelte hevde, at HR-A kan bidra med prediktive analyser (Fitz-enz \& Mattox, 2014), men det er trolig et ambisiøst og tveegget sverd. Det er nærliggende å tenke, at analytikerne i praksis vil leve med et betydelig forventningspress. Analysene skal påvise avkastningen av organisatoriske tiltak inklusive HR-A. Og uten påviselige resultat vil deres legitimitet kunne bli truet.

Selv der HR-A initieres basert på de beste intensjoner, kan en pervertering av disse intensjonene finne sted. I ledelse, som kan ses som en mangefasettert praksis i komplekse sosiale systemer, er det grunn til å innta en skeptisk holdning til universelle oppskrifter på, hvordan dette skal utøves. Hans Skjervheim forstod det å tolke praksis etter modell av tekniske handlinger som «Det instrumentalistiske mistaket» (Skjervheim, 1996, s. 241). Han mente, dette primært ikke var en moralsk, men snarere en intellektuell feiltakelse (ibid, s. 249). Denne intellektuelle feiltakelsen, denne «tankefeilen», mente Skjervheim å finne i flere forsøk på å absoluttere en bestemt form for teori (Sørbø, 2002). Nå kan en innvende, at HR-A ikke er en ideologi eller en mote, som former politikken eller makroforhold direkte. Samtidig er det ingen grunn til å bagatellisere betydningen av populært tankegods om, hvordan arbeid skal organiseres, ledes og forvaltes.

\section{E. Oppsummering}

Vi avslutter med å peke på, at det i tekstene om HR-A gis betydelige løfter. Spørsmålet er, om konseptet og dets preskripsjoner kan bære disse forventningene. Vi har sett, at HR-A inngår i tre diskurser. Den ene er bidraget til intendert strategi og implementering av strategi på virksomhetsnivå. Den andre er evidensbasert ledelse. Den tredje omhandler bygging av 
organisatoriske kapabiliteter, og kan ha potensial til å knytte mikro og makro bedre sammen i HRM som fag. Alle har det til felles at det er et ønske å heve HR-funksjonens og HRM fagets status. I sum gjør dette, at HR-A som fenomen har ulike former og betydninger. Praktikerne står overfor en krevende oppgave, når disse høye ambisjonene skal realiseres.

Denne artikkelen har klare begrensninger, først og fremst ved, at den er en innholdsanalyse av faglige tekster om HR-A. Den konseptuelle tilnærmingen gjør at konklusjonene bør ses som tentative. Vi har samtidig argumentert for, at dette er en betimelig form for analyse siden HR-A er en ung disiplin. Samtidig har vi pekt på to rudimentære hypoteser, som med fordel kan undersøkes i fremtidig forskning. For det første bør man empirisk forske på, om HR-A er et for ambisiøst konsept, til at den vurderes som realistisk i mange virksomheter. For det andre kan man med stor fordel knytte forskningen på HR-A til de fagtradisjonene, som undersøker organisatorisk klima og effekten av økt bruk av registrering og måling på arbeidsplassen.

\section{Referanser}

Abrahamson, E. (1996). Management fashion. (management fads). Academy of Management Review, 21(1), 254. https://doi.org/10.2307/258636

Angrave, D., Charlwood, A., Kirkpatrick, I., Lawrence, M. \& Stuart, M. (2016). HR and analytics: why HR is set to fail the big data challenge. Human Resource Management Journal, 26(1), 1-11.

https://doi.org/10.1111/1748-8583.12090

Bassi, L. (2011). Raging debates in HR analytics. People \& Strategy, 34(2), 14.

Benders, J. \& Verlaar, S. (2003). Lifting parts: putting conceptual insights into practice. International Journal of Operations \& Production Management, 23(7), 757-774.

https://doi.org/10.1108/01443570310481540

Boglind, A., Hällsten, F. \& Thilander, P. (2014). HR-transformation på svenska : om organisering av HR-arbete. Lund: Studentlitteratur.

Bondarouk, T., Parry, E. \& Furtmueller, E. (2017). Electronic HRM: four decades of research on adoption and consequences. The International Journal of Human Resource Management, 28(1), 98131. https://doi.org/10.1080/09585192.2016.1245672

Boon, C., Paauwe, J., Boselie, P. \& Den Hartog, D. (2009). Institutional pressures and HRM: developing institutional fit. Personnel Review, 38(5), 492-508. https://doi.org/10.1108/00483480910978018 Boxall, P. \& Purcell, J. (2016). Strategy and human resource management (4th ed. utg.). London: Palgrave MacMillan.

Budd, J. W. (2020). The psychologisation of employment relations, alternative models of the employment relationship, and the OB turn. Human Resource Management Journal, 30(1), 73-83. https://doi.org/10.1111/1748-8583.12274 
Caldwell, C., Truong, D., Linh, P. \& Tuan, A. (2011). Strategic Human Resource Management as Ethical Stewardship. Journal of Business Ethics, 98(1), 171-182.

https://doi.org/10.1007/s10551-010-0541-y

Deloitte. (2019). Leading the social enterprise: Reinvent with a human focus. Hentet 26. februar 2020 fra https://www2.deloitte.com/us/en/insights/focus/human-capital-trends.html

Døving, E. \& Nordhaug, O. (2010). Fra HRM til strategisk HR-styring. I G. Ladegaard, \& Vaabo, S (Red.), Ledelse og styring. Bergen: Fagbokforl.

Edwards, M., Charlwood, A., Guenole, N. \& Marler, J. (2018). Special Issue Call for Papers HR/People Analytics and Human Resource Management. Human Resource Management Journal, 28.

Einarsen, S. \& Skogstad, A. (2015). Ledelse på godt og vondt (2. utg. utg.). Bergen: Fagbokforl.

Fitz-enz, J. \& Mattox, J. (2014). Predictive analytics for human resources. Hobokjen, New Jersey: Wiley. https://doi.org/10.1002/9781118915042

Geertz, C. \& Darnton, R. (2017). The interpretation of cultures : selected essays (3rd ed. utg.). New York: Basic Books.

Gilje, N. \& Grimen, H. (1995). Samfunnsvitenskapenes forutsetninger : innføring $i$ samfunnsvitenskapenes vitenskapsfilosofi (2. utg. utg.). Oslo: Universitetsforl.

Godard, J. (2020). Psychologisation revisited. Human Resource Management Journal, 30(1), 84-85. https://doi.org/10.1111/1748-8583.12273

Greasley, K. \& Thomas, P. (2020). HR analytics: The onto-epistemology and politics of metricised HRM. Human Resource Management Journal, 14. https://doi.org/10.1111/1748-8583.12283

Guenole, N., Ferrar, J. \& Feinzig, S. (2017). The power of people : learn how successful organizations use workforce analytics to improve business performance. United States: Pearson Education.

Guest, D. \& King, Z. (2004). Power, Innovation and Problem-Solving: The Personnel Managers' Three Steps to Heaven? Journal of Management Studies, 41(3), 401-423. https://doi.org/10.1111/j.1467$\underline{6486.2004 .00438 . x}$

Hamilton, R. H. \& Sodeman, W. A. (2020). The questions we ask: Opportunities and challenges for using big data analytics to strategically manage human capital resources. Business Horizons, 63(1), 85-95. https://doi.org/10.1016/j.bushor.2019.10.001

Harley, B. (2015). The one best way? 'Scientific' research on HRM and the threat to critical scholarship. Human Resource Management Journal, 25(4), 399. https://doi.org/10.1111/1748$\underline{8583.12082}$ 
HR Norge, H., Flora, Sveriges HR Förening, Ey. (2017). Nordic HR Study 2017 - HR`s view on future organizational challenges and opportunities. Hentet fra https://hrnorge.no/presse/eapmnewsletter-the-impact-of-digitalization

Huselid, M. A. (2018). The science and practice of workforce analytics: Introduction to the HRM special issue. Human Resource Management, 57(3), 679-684. https://doi.org/10.1002/hrm.21916

Julsrud, T. E. (2018). Organisatorisk tillit : grunnlaget for samarbeid i nettverkenes tid. Bergen: Fagbokforl.

Kaufman, B. E. (2015). Evolution of Strategic HRM as Seen Through Two Founding Books: A 30th Anniversary Perspective on Development of the Field. Human Resource Management, 54(3), 389407. https://doi.org/10.1002/hrm.21720

Kaufman, B. E. (2020). The real problem: The deadly combination of psychologisation, scientism, and normative promotionalism takes strategic human resource management down a 30-year dead end. Human Resource Management Journal, 30(1), 49-72. https://doi.org/10.1111/17488583.12278

Kuvaas, B. \& Dysvik, A. (2016). Lønnsomhet gjennom menneskelige ressurser : evidensbasert HRM (3. utg. utg.). Bergen: Fagbokforl.

Laudal, T. \& Mikkelsen, A. (2014). Ulike tilnærminger til organisasjoner og konsekvenser for HRM. I A. Mikkelsen \& T. Laudal (Red.), Strategisk HRM 1 (s. 2 b. : ill.). [Oslo]: Cappelen Damm akademisk.

Lawler, E. E., III, Levenson, A. \& Boudreau, J. W. (2004). HR metrics and analytics: use and impact. Human Resource Planning, 27(4), 27.

Levenson, A. (2005). Harnessing the power of HR analytics. Strategic HR Review, 4(3), 28-31. https://doi.org/10.1108/14754390580000607

Levenson, A. (2018). Using workforce analytics to improve strategy execution. Human Resource Management, 57(3), 685-700. https://doi.org/10.1002/hrm.21850

Madsen, D. Ø. (2017). Examining the popularity trajectory of outsourcing as a management concept. Problems and perspectives in management, 15(2). https://doi.org/10.21511/ppm.15(2-1).2017.02

Madsen, D. Ø. \& Slåtten, K. (2018). HR-analyse som ledelseskonsept og ledelsesmote.

Samfundslederskab i Skandinavien, 33(1), 42-66.

https://doi.org/https://doi.org/10.22439/sis.v33i1.5540

Marler, J. H. \& Boudreau, J. W. (2017). An evidence-based review of HR Analytics. The International Journal of Human Resource Management, 28(1), 3-26.

https://doi.org/10.1080/09585192.2016.1244699

Mikkelsen, A. L., Thomas. (2014). Strategisk HRM : 1 : Ledelse, organisasjon, strategi og regulering (bd. 1). Oslo: Cappelen Damm akademisk. 
Minbaeva, D. B. (2018). Building credible human capital analytics for organizational competitive advantage. Human Resource Management, 57(3), 701-713. https://doi.org/10.1002/hrm.21848

Mintzberg, H., Ahlstrand, B. \& Lampel, J. (2009). Strategy safari : the complete guide through the wilds of strategic management (2nd ed. utg.). Harlow: FT/Prentice Hall.

Mondore, S., Douthitt, S. \& Carson, M. (2011). Maximizing the impact and effectiveness of hr analytics to drive business outcomes. People \& Strategy, 34(2), 20.

Morrell, K. \& Learmonth, M. (2015). Against Evidence-Based Management, for Management Learning.

Nordhaug, O. (1987). Introduksjon: Fra forvaltning til strategisk ledelse av personalressurser. I O.

Nodhaug (Red.), Strategisk personalledelse: menneskelige ressurser i omstilling. Oslo: Tano.

Pfeffer, J. \& Sutton, R. I. (2006). Evidence-based management.(Decision Making). Harvard Business Review, 84(1), 63.

Purcell, J. (2014). Disengaging from engagement. Human Resource Management Journal, 24(3), 241254. https://doi.org/10.1111/1748-8583.12046

Rasmussen, T. \& Ulrich, D. (2015). Learning from practice: how HR analytics avoids being a management fad. Organizational Dynamics, 44(3), 236-242.

https://doi.org/10.1016/j.orgdyn.2015.05.008

Rasmussen, T. H. (2014). Målbar HR : en praktisk guide til datadrevet HR-ledelse. København: Dansk psykologisk forlag.

Rynes, S. L., Colbert, A. E. \& Brown, K. G. (2002). HR Professionals' beliefs about effective human resource practices: correspondence between research and practice. Human Resource Management, 41(2), 149-174. https://doi.org/10.1002/hrm.10029

Rynes, S. L., Giluk, T. L. \& Brown, K. G. (2007). The very separate worlds of academic and practitioner periodicals in human resource management: implications for evidence-based management.(Report). Academy of Management Journal, 50(5), 987. https://doi.org/10.5465/AMJ.2007.27151939

Shah, N., Irani, Z. \& Sharif, A. M. (2017). Big data in an HR context: Exploring organizational change readiness, employee attitudes and behaviors. Journal of Business Research, 70, 366-378. https://doi.org/10.1016/j.jbusres.2016.08.010

Skjervheim, H. (1996). Deltakar og tilskodar og andre essays ([Ny utg.]. utg.). Oslo: Aschehoug.

Sparrow, P. (2015). The Analysis of HR Departments and the Contribution of David Ulrich.

Stinchcombe, A. L. \& Merton, R. K. (1968). Constructing social theories. New York: Harcourt, Brace \& World.

Sørbø, J. I. (2002). Hans Skjervheim : ein intellektuell biografi. Oslo: Samlaget. 
Torrington, D. \& Hall, L. (1996). Chasing the rainbow: how seeking status through strategy misses the point for the personnel function. Employee Relations, 18(6), 81-97.

https://doi.org/10.1108/01425459610151475

Troth, A. C. \& Guest, D. E. (2019). The case for psychology in human resource management research. Human Resource Management Journal, <xocs:firstpage xmlns:xocs=""/>. https://doi.org/10.1111/1748-8583.12237

Ulrich, D. \& Dulebohn, J. H. (2015). Are we there yet? What's next for HR? Human Resource Management Review, 25(2), 188-204. https://doi.org/10.1016/j.hrmr.2015.01.004

Watson, T. (2007). Organization Theory and HRM. I P. Boxall, P. M. Wright \& J. Purcell (Red.), The Oxford handbook of human resource management. Oxford: Oxford University Press.

Weber, M. (2019). Economy and Society: A New Translation (Originally published 2019 ; Im Original erschienen 2019. utg.). Cambridge, MA and London, England: Cambridge, MA and London, England: Harvard University Press. 